\title{
Colonial Archives and the Arts of Governance
}

\author{
ANN LAURA STOLER \\ Department of Anthropology, University of Michigan, Ann Arbor MI 48109-1382 USA \\ (E-mail:astoler@umich.edu)
}

\begin{abstract}
Anthropologists engaged in post-colonial studies are increasingly adopting an historical perspective and using archives. Yet their archival activity tends to remain more an extractive than an ethnographic one. Documents are thus still invoked piecemeal to confirm the colonial invention of certain practices or to underscore cultural claims, silent. Yet such mining of the content of government commissions, reports, and other archival sources rarely pays attention to their peculiar placement and form. Scholars need to move from archive-assource to archive-as-subject. This article, using document production in the Dutch East Indies as an illustration, argues that scholars should view archives not as sites of knowledge retrieval, but of knowledge production, as monuments of states as well as sites of state ethnography. This requires a sustained engagement with archives as cultural agents of "fact" production, of taxonomies in the making, and of state authority. What constitutes the archive, what form it takes, and what systems of classification and epistemology signal at specific times are (and reflect) critical features of colonial politics and state power. The archive was the supreme technology of the late nineteenth-century imperial state, a repository of codified beliefs that clustered (and bore witness to) connections between secrecy, the law, and power.
\end{abstract}

Keywords: archives, archiving, bureaucracy, colonial archives, ethnography, knowledge

Genealogy is gray, meticulous and patiently documentary. It operates on a field of entangled and confused parchments, on documents that have been scratched over and recopied many times. ${ }^{1}$

This essay is about the colonial order of things as seen through its archival productions. It asks what insights about the colonial might be gained from attending not only to colonialism's archival content, but to its particular and sometimes peculiar form. Its focus is on archiving as a process rather than to archives as things. It looks to archives as epistemological experiments rather than as sources, to colonial archives as cross-sections of contested knowledge. Most importantly, it looks to colonial archives as both transparencies on which power relations were inscribed and intricate technologies of rule in themselves. Its concerns are two: to situate new approaches to colonial

1 Michel Foucault, "Nietzsche, Genealogy, History”, in Daniel Bouchard (ed.), Language, Counter-Memory, Practice: Selected Essays and Interviews by Michel Foucault (Ithaca: Cornell University Press [1971] 1977), p. 139. 
archives within the broader "historic turn" of the last two decades and to suggest what critical histories of the colonial have to gain by turning further toward a politics of knowledge that reckons with archival genres, cultures of documentation, fictions of access, and archival conventions. ${ }^{2}$

\section{Epistemological scepticism, archives, and the "historic turn"}

Some four decades after British social anthropologist E.E. Evans-Pritchard's unheeded warning that anthropology would have to choose between being history or being nothing, and Claude Levi-Strauss' counter claim that accorded history neither "special value" nor privileged analytic space, students of culture have taken up a transformative venture, celebrating with unprecedented relish what has come to be called "the historic turn." Some might argue that anthropology's engagement with history over the last two decades, unlike that recent "turn" in other disciplines, has not been a turn at all, but rather a return to its founding principles: enquiry into cumulative processes of cultural production. but without the typological aspirations and evolutionary assumptions once embraced. Others might counter that the feverish turn to history represents a significant departure from an earlier venture, a more explicit rupture with anthropology's long-standing complicity in colonial politics. ${ }^{4}$ As such, one could argue that the historic turn signals not a turn to history per se, but a different reflection on the politics of knowledge - a further rejection of the categories and cultural distinctions on which

2 On the "historic turn," see the introduction to Terrence J. McDonald (ed.), The Historic Turn in the Human Sciences (Ann Arbor: University of Michigan Press, 1966). This essay represents a condensed version of Chapter 1 from my book in progress, Along the Archival Grain (Princeton: Princeton University Press). Parts of it are based on the 1996 Lewis Henry Morgan Lectures delivered at the University of Rochester entitled "Ethnography in the Archives: Movements on the Historic Turn." A different version of this piece appears in Carolyn Hamilton (ed.), Refiguring the Archive (forthcoming).

3 E.E. Evans-Pritchard, "Social Anthropology: Past and Present, The Marett Lecture, 1950”, Social Anthropology and Others Essays (New York: Free Press, 1951), p. 152. Claude Levi-Strauss, The Savage Mind (Chicago: Chicago University Press, 1966), p. 256.

4 For some sense of the range of different agendas of the current "historic turn," see Nicholas B. Dirks, Geoff Eley, and Sherry B. Ortner (eds.), Culture, Power, History: A Reader in Contemporary Social Theory (Princeton: Princeton University Press, [1983] 1994), Terrence J. McDonald (ed.), The Historic Turn in the Human Sciences (Ann Arbor: University of Michigan Press, 1996); specifically on history in the anthropological imagination, see Gerald Sider and Gavin Smith (eds.), Between History and Histories: The Making of Silences and Commemorations (Toronto: Toronto University Press, 1997). Also see Richard Fox's "For a Nearly New Culture History", in Richard G. Fox (ed.), Recapturing Anthropology: Working in the Present (Santa Fe: School of American Research Press, 1991), pp. 93-114, and James Faubion, "History in Anthropology", Annual Review of Anthropology 22 (1993): 35-54. 
imperial rule was once invested and on which post-colonial state practices have continued to be based.

Engagement with the uses and abuses of the past pervades many academic disciplines, but nowhere more than in this burgeoning area of colonial ethnography. Over the last decade, students of the colonial have challenged the categories, conceptual frame, and practices of colonial authorities and their taxonomic states. ${ }^{5}$ Questioning the making of colonial knowledge, and the privileged social categories it produced, has revamped what students of the colonial take to be sources of knowledge and what to expect of them. Attention to the intimate domains in which colonial states intervened has prompted reconsideration of what we hold to be the foundations of European authority and its key technologies. ${ }^{6}$ In treating colonialism as a living history that informs and shapes the present rather than as a finished past, a new generation of scholars are taking up Michel De Certeau's invitation to "prowl" new terrain as they re-imagine what sorts of situated knowledge have produced both colonial sources and their own respective locations in the "historiographic operation."7 Some students of colonialism are rereading those archives and doing oral histories with people who lived those archived events to comment on colonial narratives of them. ${ }^{8}$ Others are doing so with photography, engravings, and documentary art. ${ }^{9}$ Some are attending to how colonial documents have been requisitioned and recycled to confirm old entitlements or to make new political demands. As part of a wider impulse, we are no longer studying things, but the making of them. Students of colonialisms in and outside of anthropology are spending as much time rethinking what constitutes the colonial archive as they are reconsidering how written

\footnotetext{
5 See, for example, the introductions to and essays in Nicholas Dirks (ed.), Colonialism and Culture (Ann Arbor: University of Michigan Press, 1992); and in Frederick Cooper and Ann Laura Stoler (eds.), Tensions of Empire: Colonial Cultures in a Bourgeois World (Berkeley: University of California Press, 1997).

6 See "Genealogies of the Intimate", in Ann Laura Stoler and Frederick Cooper (eds.), Carnal Knowledge and Imperial Power: Race and the Intimate in Colonial Rule (Berkeley: University of California Press, 2002).

7 See Michel de Certeau, "The Historiographic Operation" (1974), in The Writing of History (New York: Columbia University Press, 1988).

8 On archives in relationship to popular memory, see Richard Price, Convict and the Colonel: A Story of Colonialism and Resistance in the Caribbean (Boston: Beacon Press, 1998); Luise White, Speaking with Vampires: Rumor and History in Colonial Africa (Berkeley: University of California Press, 2000); Ann Laura Stoler and Karen Strassler, "Castings for the Colonial: Memory Work in 'New Order' Java", Comparative Studies in Society and History 42(1) (2000): 4-48, and the references therein.

9 On the power of images in the making of colonial rule, see Elizabeth Edwards, guest editor, "Anthropology and Colonial Endeavour", in The History of Photography 21(1) (Spring 1997).
} 
documents collide and converge with colonial memories in the post-colonial field.

If Evans-Pritchards' warning some thirty-five years ago that "anthropologists have tended to be uncritical in their use of documentary sources" had little resonance at the time, it certainly has more today. For however deep and full the archival turn has been in post-colonial scholarship of the 1990s, what is more surprising is how thin and tentative it can still remain. ${ }^{10}$ Anthropologists may no longer look at archives as the stuff of another discipline. Nor are these archives treated as inert sites of storage and conservation. ${ }^{11}$ But archival labour tends to remain more an extractive enterprise than an ethnographic one. Documents are still invoked piecemeal and selectively to confirm the colonial invention of traditional practices or to underscore cultural claims.

Anthropology has never committed itself to "exhaust" the sources, as Bernard Cohn once chided the historical profession for doing with such moral fervor. But the extractive metaphor remains relevant to both. ${ }^{12}$ Students of the colonial experience "mine" the content of government commissions and reports, but rarely attend to their peculiar form or context. We look at exemplary documents rather than at the sociology of copies, or what claims to truth are lodged in the rote and redundant. We warily quote examples of colonial excesses - if uneasy with the pathos and voyeurism that such citations entail. We may readily mock fetishisms of the historian's craft, but there remains the shared conviction that access to what is "classified" and "confidential" are the coveted findings of sound and shrewd intellectual labours. ${ }^{13}$ The ability to procure them measures scholarly worth. Not least is the shared conviction that such guarded treasures are the sites where the secrets of the colonial state are really stored.

There are a number of ways to frame the sort of challenge I have in mind, but at least one seems obvious: steeped as students of culture have been in treating ethnographies as texts, we are just now critically reflecting on the making of documents and how we choose to use them, on archives not as sites of knowledge retrieval but of knowledge production, as monuments of states as well as sites of state ethnography. This is not a rejection of colonial

\footnotetext{
10 E.E. Evans-Pritchard, Anthropology and History (Manchester: Manchester University Press, 1961), p. 5.

11 See Carlo Ginzburg, Clues, Myths, and the Historical Method (Baltimore: Johns Hopkins University, 1989).

12 Bernard Cohn, "History and Anthropology: The State of Play", Comparative Studies in Society and History 22(2) (1980): 198-221.

13 On the trips to archives as "feats of [male] prowess" in nineteenth-century middle-class culture, see Bonnie G. Smith, "Gender and the Practices of Scientific History: The Seminar and Archival Research in the Nineteenth-Century", American Historical Review 100(4-5) (1995): 1150-1176.
} 
archives as sources of the past. Rather, it signals a more sustained engagement with those archives as cultural artifacts of fact production, of taxonomies in the making, and of disparate notions of what made up colonial authority.

As both Ranajit Guha and Greg Dening long have warned, "sources" are not "springs of real meaning," "fonts" of colonial truths in themselves. ${ }^{14}$ Whether documents are trustworthy, authentic, and reliable remain pressing questions, but a turn to the social and political conditions that produced those documents, what Carlo Ginzburg has called their "evidentiary paradigms," has altered the sense of what trust and reliability might signal and politically entail. The task is less to distinguish fiction from fact than to track the production and consumption of those "facts" themselves. With this move, colonial studies is steering in a different direction, toward enquiry into the grids of intelligibility that produced those "evidential paradigms" at a particular time, for a particular social contingent, and in a particular way. ${ }^{15}$

Students of the colonial have come to see appropriations of colonial history as infused with political agendas, making some stories eligible for historical rehearsal and others not. ${ }^{16}$ Troubling questions about how personal memories are shaped and effaced by states too has placed analytic emphasis on how past practices are winnowed for future uses and future projects. ${ }^{17}$ Such queries invite a turn back to documentation itself, to the "teaching" task that the Latin root "docere" implies, to what and who were being educated in the bureaucratic shuffle of rote formulas, generic plots, and prescriptive asides that make up the bulk of a colonial archive. The issue of official "bias" gives way to a different challenge: to identifying the conditions of possibility that shaped what could be written, what warranted repetition, what competencies were rewarded in archival writing, what stories could not be told, and what could not be said. Andrew Ashforth may have overstated the case in his study of South Africa's Native Affairs Commission, when he noted that "the real seat of power" in modern states is "the bureau, the locus of writing," but he

\footnotetext{
14 Ranajit Guha, "The Proses of Counter-Insurgency", in Nicholas B. Dirks, Geoff Eley, and Sherry B. Ortner (eds.), Culture, Power, History: A Reader in Contemporary Social Theory (Princeton: Princeton University Press, [1983] 1994), pp. 336-371. Greg Dening, The Death of William Gooch: A History's Anthropology (Honolulu: Hawaii University Press, 1995), p. 54.

15 Carlo Ginzburg, "Clues: Roots of an Evidential Paradigm", in Clues, Myths and the Historical Method Baltimore: Johns Hopkins University Press, 1989), pp. 96-125.

16 David William Cohen, Burying SM: The Politics of Knowledge and the Sociology of Power in Africa (Portsmouth, NH: Heineman, 1992).

17 Joanne Rappaport, Cumbe Reborn: An Andean Ethnography of History (Chicago: University of Chicago Press, 1994). Also see the contributions to Sarah Nuttall and Carli Coetzee (eds.), Negotiating the Past: The Making of Memory in South Africa (Cape Town: Oxford University Press, 1998).
} 
may not have been far off the mark. ${ }^{18}$ That every document comes layered with the received account of earlier events and the cultural semantics of a political moment makes one point clear. What constitutes the archive, what form it takes, and what systems of classification signal at specific times are the very substance of colonial politics.

\section{From extraction to ethnography in the colonial archives}

The transformation of archival activity is the point of departure and the condition of a new history. ${ }^{19}$

If one could say that archives were once treated as a means to an end by students of history, this is no longer the case today. The pleasures of "a well-stocked manuscript room with its ease of access and aura of quiet detachment" is a thing of the past. ${ }^{20}$ Over the last decade, epistemological scepticism has taken cultural and historical studies by storm. A focus on history as narrative, and on history-writing as a charged political act, has made the thinking about archives no longer the pedestrian preoccupation of "spade-work" historians or flat-footed archivists, nor the entry requirements of fledgling initiates compelled to show mastery of the tools of their trade. The "archive" has been elevated to new theoretical status, with enough cachet to warrant distinct billing, worthy of scrutiny on its own. Jacques Derrida's Archive Fever compellingly captured that impulse by giving it a name and by providing an explicit and evocative vocabulary for its legitimation in critical theory. ${ }^{21}$ But Natalie Zemon Davis' Fiction in the Archives, Roberto Ecchevaria's Myth and Archive, Thomas Richards' Imperial Archive, and Sonia Coombe's Archives Interdites, to name but a few, suggest that Derrida's splash came only after the archival turn had already been made. ${ }^{22}$

\footnotetext{
18 See Andrew Ashforth, The Politics of Official Discourse in Twentieth-Century South Africa (Oxford: Clarendon Press, 1990), p. 5.

19 De Certeau (1988 [1974]), p. 75.

20 A phrase used by Jane Sherron De Hart to underscore the "problematics of evidence" in contemporary historical reconstruction: see "Oral Sources and Contemporary History: Dispelling Old Assumptions", Journal of American History (September 1993), p. 582.

21 Jacques Derrida, Archive Fever: A Freudian Impression (Chicago: Chicago University Press, 1995).

22 Natalie Zemon Davis, Fiction in the Archives: Pardon Tales and Their Tellers in Sixteenth-Century France (Stanford: Stanford University Press, 1987); Thomas Richards, The Imperial Archive: Knowledge and the Fantasy of Empire (London: Verso, 1993); Roberto Gonzalez Echevarria, Myth and Archive: A Theory of Latin American Narrative (Cambridge: Cambridge University Press, 1990); Sonia Coombe, Archives Interdites: Les peurs françaises
} 
This move from archive-as-source to archive-as-subject gains its contemporary currency from a range of different analytic shifts, practical concerns, and political projects. For some, as in the nuanced archival forays of Greg Dening, it represents a turn back to the meticulous "poetics of detail." ${ }^{23}$ To others, like Michel-Rolph Trouillot, in his treatment of the archival silences of the Haitian Revolution, and David William Cohen, in his "combings of history," it signals a new grappling with the production of history, what accounts get authorized, what procedures were required, and what about the past it is possible to know. ${ }^{24}$ For Bonnie Smith, research in archives, like the university seminar, were the nineteenth-century sites where historical science was marked with gendered credentials. ${ }^{25}$ Archivists obviously have also been thinking about the nature and history of archives for sometime. ${ }^{26}$ What marks this moment are the profusion of forums in which historians are joining archivists in new conversations about documentary evidence, record keeping, and archival theory. ${ }^{27}$ Both are worrying about the politics of storage, what

face à l'Histoire contemporaine (Paris: Albin Michel, 1994). See also Dominick LaCapra, "History, Language, and Reading", American Historical Review 100.3 (June 1995): 807, where he also notes that the "problem of reading in the archives has increasingly become a concern of those doing archival research."

23 See, for example, Greg Dening, The Death of William Gooch: A History's Anthropology (Honolulu: University of Hawaii Press, 1995).

24 Michel-Rolph Trouillot, Silencing the Past: Power and the Production of History (Boston: Beacon Press, 1995); The Combing of History (Chicago: Chicago University Press, 1994).

25 Bonnie G. Smith, "Gender and the Practices of Scientific History", American Historical Review 100(4-5) (1995): 1150-1176.

26 On the history of archives and how archivists have thought about it, see Ernst Posner's classic essay, "Some Aspects of Archival Development since the French Revolution", in Maygene Daniels and Timothy Walch (eds.), A Modern Archives Reader (Washington, D.C.: National Archives and Record Service, [1940] 1984), pp. 3-21; Michel Duchein, "The History of European Archives and the Development of the Archival Profession in Europe", American Archivist 55 (Winter 1992): 14-25; and Terry Cook, "What is Past is Prologue: A History of Archival Ideas Since 1898, and the Future Paradigm Shift", Archivaria 43 (Spring 1997): $17-63$.

27 See, for example, Richard Berner, Archival Theory and Practice in the United States: An Historical Analysis (Seattle: University of Washington Press, 1983); Kenneth E. Foote, "To Remember and Forget: Archives, Memory, and Culture", American Archivist 53(3) (1990): 378-393; Terry Cook, "Mind over Matter: Towards a New Theory of Archival Appraisal", in Barbara Craig (ed.), The Archival Imagination: Essays in Honour of Hugh A. Taylor (Ottawa: Association of Canadian Archivists, 1992), pp. 38-69; James M. O'Toole, "On the Idea of Uniqueness", American Archivist 57(4) (1994): 632-659. For some sense of the changes in how archivists themselves have framed their work over the last fifteen years, see many of the articles in The American Archivist and Archivaria. 
information matters, and what should be retained in the archive as paper collections give way to digital forms. ${ }^{28}$

In cultural theory, "the archive" has a capital "A," is figurative, and leads elsewhere. It may represent neither material site nor a set of documents. Rather, it may serve as a strong metaphor for any corpus of selective forgettings and collections - and, as importantly, for the seductions and longings that such quests for, and accumulations of, the primary, originary, and untouched entail. ${ }^{29}$ For those inspired more directly by Foucault's Archaeology of Knowledge, the archive is not an institution, but "the law of what can be said," not a library of events, but "that system that establishes statements as events and things," that "system of their enunciabilities." 30

From whichever vantage point - and there are more than these - the "archival turn" registers a rethinking of the materiality and imaginary of collections and what kinds of truth-claims lie in documentation. ${ }^{31}$ Such a "archival turn" converges with a profusion of new work in the history of science, that is neither figuratively or literally about archives at all. I think here of Ian Hacking's studies of the political history of probability theory and state investments in the "taming of chance;" Steven Shapin's analysis of the social history of scientific truths where he traces the power to predict as one enjoyed by, and reserved for, cultured and reliable men; Mary Poovey's work on how the notion of the "modern fact" was historically produced; Alain Desrosières study (among many others) on statistics as a science of the state and Silvana Patriarca's on statistics as a modern mode of representation; Lorraine Daston's analysis of the development of classical probability theory as a means of measuring the incertitudes of a modernizing world. ${ }^{32}$ One could

\footnotetext{
28 Terry Cook, "Electronic Records, Paper Minds: The Revolution in Information Management and Archives in the Post-Custodial and Post-Modernist Era", Archives and Manuscripts 22(2) (1994): 300-329.

29 This metaphoric move is most evident in contributions to the two special issues of History of the Human Sciences devoted to "The Archive", 11(4) (November 1998) and 12(2) (May 1999). Derrida's valorization of "the archive" as imaginary and metaphor predominates both. On the archive as metaphor, also see Allan Sekula. "The Body and the Archive", October 39 (Winter 1986): 3-64.

30 Michel Foucault, "The Statement and the Archive", The Archaeology of Knowledge and the Discourse on Language, especially Part III (1972), pp. 79-134.

31 See, for example, Patrick Geary, Phantoms of Remembrance: Memory and Oblivion a the End of the First Millennium (Princeton: Princeton University Press, 1994), especially "Archival Memory and the Destruction of the Past", pp. 81-114.

32 Ian Hacking, The Taming of Chance (New York: Cambridge University Press, 1990); Steven Shapin, A Social History of Truth: Civility and Science in Seventeenth-Century England (Chicago: Chicago University Press, 1994); Mary Poovey, A History of the Modern Fact: Problems of Knowledge in the Sciences of Wealth and Society (Chicago: Chicago University Press, 1998); Alain Desrosières, The Politics of Large Numbers: A History of Statis-
} 
also add Anthony Grafton's essays on footnotes as the lines that lead into moral communities and their claims to authority and truth. ${ }^{33}$

What do these studies all have in common? All are concerned with the legitimating social coordinates of epistemologies: how people imagine they know what they know and what institutions validate that knowledge, and how they do so. None treat the conventions and categories of analysis (statistics, facts, truths, probability, footnotes, and so on) as innocuous or benign. All converge on questions about rules of reliability and trust, criteria of credence, and what moral projects and political predictabilities are served by these conventions and categories. All ask a similar set of historical questions about accredited knowledge and power - what political forces, social cues, and moral virtues produce qualified knowledges that, in turn, disqualified other ways of knowing, other knowledges. To my mind, no one set of concerns is more relevant to the colonial politics of archives and their (parent) archiving states.

But the archival turn can be traced through other venues as well, suggesting that something resembling ethnography in an archival mode has been around for sometime. Carlo Ginzburg's micro-history of a sixteenthcentury miller, like Natalie Davis' use of pardon tales in Fiction in the Archives, drew on "hostile" documents of the elites to reveal "the gap between the image underlying the interrogations of judges and the actual testimony of the accused." ${ }^{4}$ Neither were intended as ethnographies of the archive, but both gesture in that direction. In Davis' explicit attention to "how people told stories, what they thought a good story was, how they accounted for motive," these sixteenth-century letters of remission are shown to recount more than the bare facts of their peasant authors' sober tales. ${ }^{35}$ Pardon tales also registered the "constraints of the law," the monopoly on public justice of royal power, and the mercy that the monarchy increasingly claimed. ${ }^{36}$ Davis' "fiction in the archives" demonstrated fashioned stories that spoke to moral

tical Reasoning (Cambridge: Harvard University Press, 1998); Silvana Patriarca, Numbers and Nationhood: Writing Statistics in Nineteenth-Century Italy (Cambridge and New York: Cambridge University Press, 1998). On the power of "suasive utterance" in the making of scientific truth-claims, see Christopher Norris, "Truth, Science, and the Growth of Knowledge", New Left Review 210 (1995): 105-123; and Benedict Anderson, "Census, Map, Museum", in the revised second edition of Imagined Communities: Reflections on the Origin and Spread of Nationalism (New York: Verso, 1991), pp. 163-186.

33 Anthony Grafton, The Footnote: A Curious History (Cambridge, MA: Harvard University Press, 1997).

34 Carlo Ginzburg, The Cheese and the Worms: The Cosmos of a Sixteenth-Century Miller (London: Penguin, 1982), pp. xvii, xviii.

35 Davis, 1987, p. 4.

36 Ibid. 
truths, drew on shared metaphors and high literary culture, and depended on the power of the state and the archived inscriptions of its authority.

While recent participants in the archival turn have been taken with Derrida's contention that "there is no political power without control of the archive," in fact, this insistence on the link between what counts as knowledge and who has power has long been a founding principle of colonial ethnography. ${ }^{37}$ Rolph Trouillot's insistence in his study of the Haitian Revolution that "historical narratives are premised on previous understandings, which are themselves premised on the distribution of archival power" allows him to track the effacement of archival traces, and the imposed silences that people have moved around and beyond. ${ }^{38}$ Nicholas Dirk's observation that early colonial historiographies in British India were dependent on native informants, who were later written out of those histories, draws our attention to the relationship between archiving, experts, and knowledge production. ${ }^{39}$ Christopher Bayly's more recent attention to the ways in which the British intelligence service in colonial India worked through native channels places the state's access to "information" as a nodal point in the art of governance and as a highly contested terrain. ${ }^{40} \mathrm{My}$ own work on "the hierarchies of credibility" that contained colonial narratives in the Netherlands Indies, as these constrained what were counted as having plausible plots, reads colonial politics off the "storeyed" distributions of the state's paper production and through the rumors (spread by a beleaguered native population) that were woven through it. ${ }^{41}$

As Foucault provocatively warned, the archive is neither the sum of all texts that a culture preserves nor those institutions that allow for that record's preservation. The archive is rather that "system of statements," those "rules of practice," that shape the specific regularities of what can and cannot be said. ${ }^{42}$ Students of colonialism have wrestled with this formulation to capture what renders colonial archives as both documents of exclusions and as monuments to particular configurations of power.

37 Derrida, 1995, p. 4.

38 Michel-Rolph Trouillot, 1995, p. 55.

39 Nicholas B. Dirks, "Colonial Histories and Native Informants: Biography of an Archive", in Carol A. Breckenridge and Peter van der Veer (eds.), Orientalism and the Postcolonial Predicament: Perspectives on South Asia (Philadelphia: University of Pennsylvania Press, 1993), pp. 279-313.

40 Christopher Bayly, Empire and Information: Intelligence Gathering and Social Communication in India, 1780-1870 (Cambridge: Cambridge University Press, 1996).

41 Ann Laura Stoler, "In Cold Blood: Hierarchies of Credibility and the Politics of Colonial Narratives", Representations 37 (1992): 151-189.

42 See Michel Foucault, "The Statement and the Archive", The Archaeology of Knowledge, pp. $79-134$. 
Both Gonzalez Echevvaria and Thomas Richards follow Foucault in treating the imperial archive as "the fantastic representation of an epistemological master pattern." ${ }^{33}$ For Richards, that archive is material and figurative, a metaphor of an unfulfilled but shared British imperial imagination. The imperial archive was both the supreme technology of the late nineteenthcentury imperial state and the telling prototype of a postmodern one, predicated on global domination of information and the circuits through which "facts" move. Echevvaria locates the archive as both relic and ruin, a repository of codified beliefs, genres for bearing witness, clustered connections between secrecy, power, and the law. ${ }^{44}$ It was the legitimating discourses of the Spanish colonial archives, he argues, that provided the Latin American novel with its specific content and thematic form. For both Richards and Echevvaria, the archive is a template that decodes something else. Both push us to think differently about archival fictions, but reserve their fine-grained analysis for literature, not the colonial archives themselves. ${ }^{45}$

Whether the "archive" should be treated as a set of discursive rules, an utopian project, a depot of documents, a corpus of statements, or all of the above, is not really the question. Colonial archives were both sites of the imaginary and institutions that fashioned histories as they concealed, revealed, and reproduced the power of the state. ${ }^{46}$ Power and control, as many scholars have pointed out, is fundamental to the etymology of the term. ${ }^{47}$ From the Latin archivum, "residence of the magistrate," and from the Greek arkhe, to command or govern, colonial archives ordered (in both the imperative and taxonomic sense) the criteria of evidence, proof, testimony, and witnessing to construct moral narrations. "Factual storytelling," moralizing stories, and multiple versions - features that Hayden White ascribes to what counts as history - make sense of which specific plots "worked" in the colonial archives as well. ${ }^{48}$ It was in factual stories that the colonial state affirmed its fictions to itself, in moralizing stories that it mapped the scope of

43 Richards, 1993, p. 11.

44 Echevvaria, 1990, p. 30.

45 Thus for Thomas Richards, Hilton's Lost Horizon and Kipling's Kim are entries in a Victorian archive that was the "prototype for a global system of domination through circulation, an apparatus for controlling territory by producing, distributing and consuming information about it."

46 This link between state power and what counts as history was long ago made by Hegel in The Philosophy of History, as Hayden White points out: "It is only the state which first presents subject-matter that is not only adapted to the prose of History, but involves the production of such history in the very progress of its own being." See Hayden White, The Content of the Form: Narrative Discourse and Historical Representation (Baltimore: Johns Hopkins, 1987), p. 12.

47 See Echevvaria (1990), p. 31, for a detailed etymology of the term.

48 See White, 1987, especially, pp. 26-57. 
its philanthropic missions, and in multiple and contested versions that cultural accounts were discredited or restored.

Viewed in this perspective, it is clear that the nineteenth- and earlytwentieth-century archives of the Dutch administration in the Indies were not to be read randomly in any which way. Issues were rendered important by how they were classed and discursively framed. Official exchanges between the Governor General and his subordinates, between the Governor General and the Minister of Colonies, and between the Minister and the King, were reference guides to administrative thinking. Organized in folio forms, title pages provided long lists of cross-referenced dossiers and decisions that were abbreviated genealogies of what constituted relevance, precedent, and "reasons of state." With appended evidence that might include testimonies of experts and commissioned reports, such folios contained and confirmed what counted as proof and who cribbed from whom in the chain of command. Attention to moments of distrust and dispersion, reversals of power, ruptures in contract, have been the trade marks of critical political and social history for some time. What has changed is an appreciation of how much the archival practices of these "paper empires" signaled changes in their technologies of rule. $^{49}$

If it is obvious that colonial archives are products of state machines, it is less obvious that they are, in their own right, technologies that bolstered the production of those states themselves. ${ }^{50}$ Systems of written accountability were the products of institutions, but paper trails (weekly reports to superiors, summaries of reports of reports, recommendations based on reports) called for an elaborate coding system by which they could be tracked. Colonial statecraft was built on the foundations of statistics and surveys, but also out of the administrative apparatus that produced that information. Multiple circuits of communication - shipping lines, courrier services, and telegraphs - were funded by state coffers and systems of taxation that kept them flush. Colonial publishing houses made sure that documents were selectively duplicated, disseminated, or destroyed. Colonial office buildings were constructed to make sure they were properly catalogued and stored. And not unlike the broader racialized regime in which archives were produced, the "mixedblood," "Indo" youths, barred from rising in the civil service ranks, were the scribes that made the system run. Employed as clerks and copyists in the colonial bureaucracy, they were commonly referred to as "copy machines," and then disdained for their lack of initiative, their poor command of Dutch,

\footnotetext{
49 On this point, see Trouillot, 1995. On the relationship between state formation and archival production, see Duchein (1992), cited above.

50 See my "Racial Histories and Their Regimes of Truth", Political Power and Social Theory 11 (1997): 183-255.
} 
and their easy adaptation to such imitative and degraded roles. Attention to this sort of scaffolding of the colonial state renders an ethnographic reading of the archives very different from what histories of the colonial looked like several decades ago.

\section{Along the archival grain}

If one were to characterize what has informed a critical approach to the colonial archives over the last fifteen years, it would be a commitment to the notion of reading colonial archives "against their grain." Students of colonialism, inspired by political economy, were schooled to write popular histories "from the bottom up," histories of resistance that might locate human agency in small gestures of refusal and silence among the colonized. ${ }^{51}$ As such, engagement with the colonial archives was devoted to a reading of "upper class sources upside down" in order to reveal the language of rule and the biases inherent in statist perceptions. ${ }^{52}$

The political project was to write "un-State-d" histories that might demonstrate the warped reality of official knowledge and the enduring consequences of such political distortions. In Ranajit Guha's formulation, colonial documents were rhetorical sleights of hand that erased the facts of subjugation, reclassified petty crime as political subversion, or simply effaced the colonized. The political stakes were put on the analytic tactics of inversion and recuperation: an effort to re-situate those who appeared as objects of colonial discipline as subaltern subjects and agents of practice who made - albeit constrained - choices of their own. Within this frame, archival documents were counterweights to ethnography, not the site of it. ${ }^{53}$

But colonial authority, and the practices that sustained it, permeated more diverse sites than those pursuing this "romance of resistance" once imagined. If Marx's insistence, that "people make their own history, but not exactly as they please," informed these early efforts to write histories of popular agency, they also underscored that colonial rule rested on more than the calculated inequities of specific relations of production and exchange. In looking more to the carefully honed cultural representations of power, students of the colonial have turned their attention to the practices that privileged certain social

\footnotetext{
51 For a more detailed account of these changes in research agenda, see the new preface to my Capitalism and Confrontation in Sumatra's Plantation, 1870-1979 (Ann Arbor: University of Michigan Press, 1995).

52 I discuss some of these issues in "Perceptions of Protest: Defining the Dangerous in Colonial Sumatra", American Ethnologist 12(4) (1985): 642-658.

53 For a recent and sophisticated version of this culling project, see Shahid Amin, Event, Metaphor, Memory: 1922-1992 (Berkeley: University of California Press, 1995).
} 
categories and made them "easy to think." Not least, we have become more suspect of colonial vocabularies themselves that surreptitiously slip away from their historical moorings and reappear as our explanatory concepts of historical practice, rather than as folk categories that need to be explained. ${ }^{54}$

Focus in colonial studies on those tensions of empire that were at once intimate and broad has placed sex and sentiment not as metaphors of empire, but as its constitutive elements. ${ }^{55}$ Appreciating how much the personal was political has revamped the scope of our archival frames: housekeeping manuals, child-rearing handbooks, and medical guides share space with classified state papers, court proceedings, and commission reports as defining texts in colonialism's cultures of documentation. Raymond Williams' pioneering treatment of culture as a site of contested, not shared, meaning has prompted students of the colonial to do the same. In turning from race as a thing to race as a porous and protean set of relations, colonial histories increasingly dwell on the seams of archived and non-archived ascriptions to redefine colonial subsumptions on a broader terrain. ${ }^{56}$ However we frame it, the issues turns on readings of the archives based on what we take to be evidence and what we expect to find. How can students of colonialisms so quickly and confidently turn to readings "against the grain" without moving along their grain first? How can we brush against them without a prior sense of their texture and granularity? How can we compare colonialisms without knowing the circuits of knowledge production in which they operated and the racial commensurabilities on which they relied? If a notion of colonial ethnography starts from the premise that archival production is itself both a process and a powerful technology of rule, then we need not only to brush against the archive's received categories. We need to read for its regularities, for its logic of recall, for its densities and distributions, for its consistencies of misinformation, omission, and mistake - along the archival grain.

Assuming we know those scripts, I would argue, diminishes our analytic possibilities. It rests too comfortably on predictable stories with familiar plots. It diverts our attention from how much colonial history-writing has been shaped by nationalist historiographies and nation-bound projects. It leaves unquestioned the notion that colonial states were first and foremost information-hungry machines in which power accrued from the massive accumulation of ever-more knowledge rather than from the quality of it.

\footnotetext{
54 See the introduction, "Genealogies of the Intimate", in my Carnal Knowledge and Imperial Power: Race and the Intimate in Colonial Rule (Berkeley: University of California Press, 2002).

55 See my "Sexual Affronts and Racial Frontiers", Comparative Studies in Society and History 34(3) (1992): 514-551.

56 See J. Chandler, A. Davidson, and H. Harootunian (eds.), Questions of Evidence: Proof, Practice and Persuasion across the Disciplines (Chicago: University of Chicago Press, 1994).
} 
It takes as a given that colonial statecraft was motivated and fueled by a reductive equation of knowledge to power, and that colonial states sought more of both. Not least, it makes irrelevant failed proposals, utopian visions, and improbable projects because they were "non-events." Reading only against the grain of the colonial archive bypasses the power in the production of the archive itself.

\section{Civilities and credibilities in archival production}

If colonial documents reflected the supremacy of reason, they also recorded an emotional economy manifest in disparate understandings of what was imagined, what was feared, what was witnessed, and what was overheard. Such a reading turns us to the structures of sentiment to which colonial bureaucrats subscribed, to the formulaic by which they abided, to the mix of dispassionate reason, impassioned plea, cultural script, and personal experience that made up what they chose to write to their superiors and thus place in the folds of official view. Dutch colonial documents register this emotional economy in several ways: in the measured affect of official texts, in the biting critique reserved for marginalia, in footnotes to official reports where assessments of cultural practice were often relegated and local knowledge was stored. Steven Shapin's set of compelling questions in his social history of truth could be that of colonial historians as well. What, he asks, counted as a credible piece of information; what was granted epistemological virtue and by what social criteria? What sentiments and civilities made for "expert" colonial knowledge that endowed some persons with the credentials to generate trustworthy truth-claims that were not conferred on others?

Colonial archives were, as Echevvaria notes, legal repositories of knowledge and official repositories of policy. But they were also repositories of good taste and bad faith. Scribes were charged with making fine-penned copies. But reports on the colonial order of things to the Governor General in Batavia, and to the Minister of Colonies in The Hague, often were composed by men of letters, whose status in the colonial hierarchy was founded as much on their display of European learning as on their studied ignorance of local knowledge, on their skill at configuring events into familiar plots, and on their cultivation of the fine arts of deference, dissemblance, and persuasion. All rested on the subtle use of their cultural know-how and cultural wares. As Fanny Colonna once noted for French Algeria, the colonial politics of knowledge penalized those with too much local knowledge and those with not enough. ${ }^{57}$ In the Indies, civil servants with too much knowledge of things

\footnotetext{
57 See Fanny Colonna, "Educating Conformity in French Colonial Algeria", in Frederick Cooper and Ann Laura Stoler (eds.), Tensions of Empire (1997), pp. 346-370.
} 
Javanese were condemned for not appreciating the virtues of limited and selective familiarity.

Christopher Bayly, in a thoughtful study of the development of an intelligence system by the British in India, argues that the mastery of "affective knowledge" was an early concern of the British colonial state, that diminished throughout the nineteenth century as that state became more hierarchical and governing became a matter of routine.$^{58}$ But I would argue the opposite: that affective knowledge was at the core of political rationality in its late colonial form. Colonial modernity hinged on a disciplining of one's agents, on a policing of the family, on Orwellian visions of intervention in the cultivation of compassion, contempt, and disdain.

The accumulation of affective knowledge was not then a stage out of which colonial states were eventually to pass. Key terms of the debates on poor whites and child-rearing practices from as late as the 1930s, just before the overthrow of Dutch rule, make that point again and again. When classified colonial documents argued against the support of abandoned mixed-blood children - that "mother care" (moederzorg) should not be replaced by "care of the state" (staatszorg) - they were putting affective responsibility at the heart of their political projects. When these same high officials wrote back and forth about how best to secure "strong attachments" to the Netherlands among a disaffected, estranged, and growing local European population, "feeling" is the word that pervades their correspondence. Dutch authorities may never have agreed on how to cultivate European sensibilities in their young, and just how early in a child's development they imagined they needed to do so. But at stake in these deliberations over "upbringing" and "rearing" were disquieted reflections on what it took to make someone "moved" by one set of sensory regimes and estranged from others. Colonial states and their authorities, not unlike metropolitan ones, had strong motivation for their abiding interest in the distribution of affect and a strong sense of why it mattered to colonial politics.

\section{Cultural logics and archival conventions}

The archive does not have the weight of tradition; and it does not constitute the library of libraries, outside time and place - it reveals the rules of practice ... its threshold of existence is established by the discontinuity that separate[s] us from what we can no longer say. ${ }^{59}$

58 Christopher Bayly, Empire and Information 1996.

59 Foucault, 1972, p. 130. 
One way to re-configure our uses of the colonial archive is to pause at, rather than bypass, its conventions, those practices that make up its unspoken order, its rubrics of organization, its rules of placement and reference. Archival conventions might designate who were reliable "sources," what constituted "enough" evidence and what - in the absence of information - could be filled in to make a credible plot. Conventions suggest consensus, but it is not clear what colonial practitioners actually shared. Archival conventions were built upon a changing collection of colonial truths about what should be classified as secrets and matters of state security, and what sorts of actions could be dismissed as prompted by personal revenge and ad hoc passion or accredited as a political subversion against the state. ${ }^{60}$ Such conventions exposed the taxonomies of race and rule, but also how skilfully, awkwardly, and unevenly both seasoned bureaucrats and fledgling practitioners knew the rules of the game.

Attention to these conventions may lead in two directions: to the consensual logics they inscribed, but also much more directly to their arbitrary rules and multiple points of dissension. Political conflicts show up in the changing viability of categories and disagreements about their use. But as Paul Starr suggests, "information out of place" - the failure of some kinds of practices, perceptions, and populations to fit into a state's ready-made system of classification - may tell as much or more. ${ }^{61}$ Commentaries on European nurseries in the colonies might be expected to turn up in reports on education, but the very fact that they consistently showed up elsewhere - in reports on European pauperism and white poor relief, or in recommendations to quell creole discontent, suggest that what was "out of place" was often sensitive, and that is was children cued to the wrong cultural sensibilities that were dangerously out of place.

\section{Colonial commissions as stories that states tell themselves}

As Ian Hacking says of social categories, archives produced as much as they recorded the realities they ostensibly only described. They told moral stories, they created precedent in the pursuit of evidence, and not least they create carefully tended histories. Nowhere is this history-making work more

\footnotetext{
60 On the administrative distinctions between the "political" and the "private," and the "criminal" versus the "subversive," see my "Perceptions of Protest: Defining the Dangerous in Colonial Sumatra", American Ethnologist 12(4) (1985): 642-658; and "Labor in the Revolution", Journal of Asian Studies 47(2): 227-247.

61 Paul Starr, "Social Categories and Claims in the Liberal State", in Mary Douglas and David Hull (eds.), How Classification Works: Nelson Goodman among the Social Sciences (Edinburgh: Edinburgh University Press, 1992), pp. 154-179.
} 
evident than in the form of the commission of inquiry or state commission. By definition, commissions organized knowledge, rearranged its categories, and prescribed what state officials were charged to know. As the anthropologist, Frans Husken, notes of Dutch commissions in colonial Java, "“when nothing else works and no decision can be reached, appoint a commission' was a favorite response of colonial authorities." 62 But commissions were not just pauses in policy and tactics of delay. Like statistics, they helped "determine ... the character of social facts" and produced new truths as they produced new social realities. ${ }^{63}$ They were responses to crisis that generated increased anxiety, substantiating the reality of that crisis itself. ${ }^{64}$ By the time most commissions had run their course (or spawned their follow-up generation), they could be credited with having defined "turning points," justifications for intervention, and, not least, expert knowledge.

The various commissions produced on the problem of poor whites in the Indies between the 1870s and early 1900s, and those carried out in South Africa between the early 1900s and the late 1920s, are exemplary of what I have in mind. There are certain general features which they share. ${ }^{65}$ Both produced published and publicized volumes: Pauperism among the Europeans (published 1901-1902), and The Problem of Poor Whites in South Africa (published 1929-1932). ${ }^{66}$ Both commissions were about indigent

\footnotetext{
62 Frans Husken, "Declining Welfare in Java: Government and Private Inquiries, 19031914", in Robert Cribb (ed.), The Late Colonial State in Indonesia (Leiden: KITLV, 1994), p. 213.

63 Ian Hacking, "How Should We Do the History of Statistics?", in Graham Burchell, Colin Gordon, and Peter Miller (eds.), The Foucault Effect: Studies in Governmentality (Chicago: Chicago University Press, 1991), p. 181.

64 A good example of what Ian Hacking calls "dynamic nominalism" or "the looping effect" in categorization.

65 I discuss the politics of colonial comparisons elsewhere and therefore will not do so here. I have used the 1902 Indies Pauperism Commission, commentaries around it, and enquiries that preceded it, in much of my writing over the last fifteen years on the construction of colonial racial categories. The South African Carnegie Commission and the enquiries that preceded it are compared in a chapter in my forthcoming book, Along the Archival Grain. A more general discussion of the politics of comparison can be found in my "Tense and Tender Ties: American History meets Postcolonial Studies," paper delivered to the Organization of American Historians in April 2000; and in my "Beyond Comparison: Colonial Statecraft and the Racial Politics of Commensurability," paper delivered as a keynote address to the Australian Historical Association in Adelaide, July 2000.

66 Students of colonialism could come up with a host of others. For an unusual example of someone who deals with the commission as a particular form of official knowledge, in this case with the South African Native Affairs Commission, see Adam Ashforth, The Politics of Official Discourse in Twentieth-Century South Africa (Oxford: Clarendon Press, 1990). Also see Frans Husken's discussion of the Declining Welfare Commission in Java, cited in footnote 62.
} 
Europeans and their inappropriate dispositions toward work, racial distance, sexual propriety, and morality. Each requisitioned administrative energy and expertise, entailed several years of labour, produced thousands of pages of text, and involved scores of interviewers and hundreds of interviewees. In the case of the Indies, its probing questionnaires on sexual unions, illegitimate children, and domestic arrangements sparked the wrath of hundreds of irate colonial Europeans, who condemned the Indies government as an "inquisitionary state." Both commissions were repositories of colonial anxieties unsettling testimonies to the insecurity of white privilege, to the ambiguities of membership in the privileged category of "European," and to the making of a public welfare policy solidly based on race. Both worried over increasing numbers of impoverished whites because they were worried about something else. As stated in the Carnegie Commission, their "propinquity of ... dwellings" to "non-Europeans" tended to bring native and white into contact, "counteract miscegenation," weaken the color line, and promote "social equality."67

These commissions could and should be read for their extraordinary ethnographic content, but also for the content evident in their form. Like other colonial commissions, they marked off clusters of people who warranted state interest and state expense. Secondly, they were redemptive texts, structured to offer predictions based on causal accounts of exoneration and blame. And thirdly, both commissions were documents to the making of state historiography and monuments to why history mattered to consolidating and imperial states. In writing the past, they produced dramatic narrative histories based on select chronologies, crystallizing moments, and significant events. In defining poverty in the present, they also dictated who in future would count as white -and therefore who would be eligible for state aid.

In doing all of the above, they wrote, revised, and over-wrote genealogies of race. Neither of these commissions were the first of their kind. On the contrary, they were made credible by how they mapped the past onto prescriptions for the present and predictions of the future. They also showed something more. How social practices were historically congealed into events and made into things: how an increase of unemployment and impoverishment among European colonials became a "problem" called "poor whiteism," with attributes of its own. "Poor whiteism" defined, physiologically and psychologically, distinct sorts of persons, with aggregated ways of "being in the world," with specific dispositions and states of mind. Like other colonial commissions, these commission were consummate producers of social kinds and social categories.

67 The Poor White Problem in South Africa, Report of the Carnegie Commission (Stellenbosch: Pro Ecclesia Drukkerij, 1932), p. xx. 
Commissions and statistics were features of statecraft in similar ways. Both are eighteenth-century inventions consolidated by the nineteenthcentury liberal state. ${ }^{68}$ Both were products and instantiations of the state's investment in public accountability. But commissions commanded more moral authority as they purported to scrutinize state practice, reveal bureaucratic mistakes, and produce new truths about the workings of the state itself. Moreover, these "poor white" commissions were quintessential products of "biopolitical" technologies. Not only did they link the relationship between parent and child, nursemaid and infant, to the security of the state; they sought ethnographic substantiation, eye-witness testimonies from participantobservers that what individuals did - whether they wore shoes, lounged on their porches, spoke Dutch or Malay, or made their children say morning prayers - were practices linked directly to the state's audit of its own viability.

Both commissions and statistics were part of the "moral science" of the nineteenth century that coded and counted society's pathologies. While statistics used deviations from the mean to identify deviations form the norm, commissions joined those numbers with stories culled from individual "cases" to measures gradations of morality. ${ }^{69}$ Commissions in turn affirmed the state's authority to make judgements about what was in society's collective and moral good. Both were prescriptive and probabilistic tools whose power was partially in their capacities to predict and divert politically dangerous possibilities.

Like statistics, the commission demonstrated the state's right to power through its will to truth. In the Indies, the Pauperism Commission conferred on the state moral authority by demonstrating its moral conscience and disinterested restraint, its willingness and commitment to critically reflect on its own mishaps, to seek the truth "at whatever cost." But its power rested in more than its calculation of the moral pulse of the present and its implications for the future. The commission justified its licence to expend funds, time, and personnel in part by rehearsing the past and remembering and reminding its readership of its enduring weight. Historical narratives shape these texts with stories that deflected the causes of deprivations and inequities away from

\footnotetext{
68 Royal commissions have a longer history still. See, for example, David Loades, "The Royal Commissions", in Power in Tudor England (New York: St. Martin's Press, 1997), pp. 70-82. On statistics and state-building, see Alain Desrosieres, "Statistics and the State", The Politics of Large Numbers (1998): 178-209. For the twentieth century, see William J. Breen, "Foundations, Statistics, and State-Building", Business History Review 68 (1994): 451-482.

69 See Arjun Appardurai's discussion of numerical representation in colonial India as a "key to normalizing the pathology of difference." "Number in the Colonial Imagination", Modernity at Large: Cultural Dimensions of Globalization (Minneapolis: University of Minnesota, 1996), pp. 114-138.
} 
the present, even as they rehearsed the enduring burden of earlier policies of administrations past.

Finally, these commissions were quintessential "quasi-state" technologies, both part of the state and not, at once a product of state agents but constituted invariably by members outside it. If modern states gain force in part by creating and maintaining an elusive boundary between themselves and civil society, as Tim Mitchell has argued, such commissions exemplified that process. ${ }^{70}$ Their specific subjects were state generated, but often researched and written by those not in its permanent employ. Both the Indies and Carnegie Commissions delegated bodies of experts equipped to assess morality (religious experts), deviance (lawyers, educators), and disease (doctors), to whom the state conferred short-term and subject-specific voice and public authority. They instantiated the ways in which the state exercised its will to power by calling on "outside" expert authorities to verify the state's ability to stand in for public interest and its commitment to the public good.

\section{Archival seductions and state secrets}

As archivists are the first to note, to understand an archive one needs to understand the institutions that it served. What subjects are cross-referenced, what parts are re-written, what quotations are cited, not only tell us about how decisions are rendered, but how colonial histories are written and remade. Information out of place underscores what categories matter, which ones become common sense and then fall out of favor. Not least they provide road maps to anxieties that evade more articulate form.

The commission is one sort of archival convention; "state secrets" are another. States traffic in the production of secrets and the selective dissemination of them. In this regard, the Dutch colonial state was gifted at its task. $^{71}$ As Weber once noted, the "official secret" was a specific invention of bureaucracy that was "fanatically defended" by it. The designations "secret," "very secret," and "confidential" registered more than fictions of denied entry and public access. Nor did they mostly signal the pressing political concerns of the colonial state. Rather, and more importantly, such codes

\footnotetext{
70 See Gramsci's discussion of "state and civil society," in Quintin Hoare and Geoffrey Smith (eds.), Selections from the Prison Notebooks of Antonio Gramsci (London: Lawrence and Wishart, 1972), esp. 257-264; and Timothy Mitchell, "The Limits of the State", American Political Science Review 85 (1991): 77-96.

71 George Simmel once wrote that "the historical development of society is in many respects characterized by the fact that what at an earlier time was manifest enters the protection of secrecy; and that, conversely, what once was a secret, no longer needs such protection but reveals itself", in Kurt Wolff (ed.) The Sociology of George Simmel (London: Free Press, 1950), p. 331.
} 
of concealment were the fetishized features of the state itself. State secrets named and produced privileged knowledge, and designated privileged readers while reminding the latter what knowledge should be coveted, and what was important to know. The secreted report, like the commission, created categories it purported to do no more than describe. In the Indies, the classified document commanded a political weight that called for secret police, paid informants, and experts.

Secrets imply limited access, but what is more striking in the Dutch colonial archives is how rarely those items classified as "confidential" (vertrouwelijk, zeer vertrouwelijk, geheim, and zeer geheim) were secrets at all. Some surely dealt with clandestine police and military tactics (such as preparations for troop movements to protect planters against an attack), but far more of these documents were about prosaic, public parts of Indies life. ${ }^{72}$ If one could argue that documents recording the disquieting presence of European beggars and homeless Dutchmen in the streets of Batavia were "secrets" to those reading them back in the Netherlands, these presences certainly were not secrets to the majority of Europeans who lived in the colony's urban centers.

What was "classified" about these reports was not their subject-matter - in this case, indigent "full-blooded" Europeans and their mixed-blood descendants - but rather the conflict among officials about how to act on the problem, their disparate assessments of what was the cause, and how many such indigents there were. Some reports were "classified" because officials could not agree on whether there were twenty-nine mixed-bloods in straitened circumstances or tens of thousands. ${ }^{73}$ In short, documents were classified as "sensitive" and "secret" sometimes because of the magnitude of a problem - other times because officials could not agree on what the problems were. But perhaps what is more surprising are the range of confidential information that students of colonialism expect them to divulge. State secrets are not necessarily secreted truths about the state, but promises of confidences shared. If state secrets are more attention-getting annotations than conventions of concealment, then how state secrets were produced, what was a secret at one time and later not, may index the changing terms of what was considered "common sense," as well as changes in political rationality. As Marc Ventresca argues in a study of why and when states count, statistical information in the eighteenth century was considered a source of state power and therefore not published. Public access to state statistics was a nineteenth-

\footnotetext{
72 Algemeen Rijksarchief (The Hague) Ministerie van Koloniën. Geheim No. 1144/2284. From the Department of Justice to the Governor General, Batavia, 29 April 1873.

73 Algemeen Rijksarchief. Verbaal 28 March 1874, no. 47. From the Department of Justice to the Governor General.
} 
century phenomenon. ${ }^{74}$ State secrets made up a basic feature of the colonial archive, a telling element in the production of fictions of access displayed by their content as well as their form.

\section{Colonial archives as "systems of expectation"}

To take up Jean and John Comaroff's invitation to "create new colonial archives of our own" may not only entail, as they rightly urge, attention to new kinds of sources, but also to different ways of approaching those we already have, different ways of reading than we have yet done. ${ }^{75}$ In turning from an extractive to a more ethnographic project, our readings need to move in new ways through archives both along their fault lines as much as against their grain. De Certeau once defined the science of history as a redistribution in space, the act of changing something into something else. He warns us that our historical labours in the archives must do more than "simply adopt former classifications," must break away from the constraints of "series $\mathrm{H}$ in the National Archives" replaced with new "codes of recognition" and "systems of expectation" of our own. But such a strategy really depends on what we think we already know. ${ }^{76}$ For students of colonialisms, such codes of recognition and systems of expectation are at the very heart of what we still need to learn about colonial polities. The breadth of global reference and span of lateral vision that colonial regimes unevenly embraced suggest that an ethnographic sensibility, rather than an extractive gesture, may be more appropriate for identifying how nations, empires, and racialized regimes were fashioned not in ways that display confident knowledge and know-how, but in disquieted and expectant modes.

\footnotetext{
74 Marc Ventresca, When States Count: Institutional and Political Dynamics in Modern Census Establishment, 1800-1993. Ph.D. thesis: Stanford University (1995), p. 50.

75 Jean and John Comaroff, Ethnography and the Historical Imagination (Boulder: Westview Press, 1992).

76 De Certeau, 1988 [1974], p. 107.
} 
